\title{
Tracing the Path to Universal Banking: The Indian Scenario
}

\author{
Chandana Goswami, PhD \\ Nilanjana Deb
}

\begin{abstract}
In India, the Commercial Banking sector has been the dominant element in the country's financial system and performed the key functions of providing liquidity and payment services to the real sector, and has accounted for bulk of the financial intermediation process. However, since early 1990s, the Indian banking sector has been subjected to various reform measures initiated by the Government at the backdrop of economy-wide structural adjustment programme and also in response to the unsatisfactory economic and qualitative performance of the Public Sector Banks owing to lack of competition, low capital base, low productivity and high intermediation cost.
\end{abstract}

Financial sector reforms have uprooted many of the outdated regulatory fences within which banks were required to carry out their activities. This provided more liberty to banks and they started exploiting different areas of operation. Gradually, many of the banks, apart from their indigenous function i.e., banking, started having substantial interests in all sorts of financial businesses like insurance, funds management, mutual funds, securities trading etc. Eventually, such a bank acquired the status of Financial Conglomerate and slowly began moving towards Universal Banking framework. However, in this process, the risk exposure of banks increased further and also it has raised a question on what should be the effective regulatory system for monitoring such conglomerates.

Therefore, an attempt is made to trace the path of transition of Indian banks towards Universal banking framework, their risk exposure, opportunities and challenges confronted in this process of transition and the regulatory system needed to monitor such entities.

Keywords: Indian bank, universal banking, risk, opportunities and challenges, regulatory framework

\section{Introduction}

In the light of global experience of diversification taken by the Banking sector as well as the emergence of the Universal Banking concept, an attempt has been made through the review of literature to trace the extent of diversification made by banks in the Indian Banking horizon and their eventual transition to Universal Banking framework, 
opportunities and challenges before domestic banks, the risks confronted in course of this transition and the regulatory and supervisory issues that are likely to arise in the Indian context on resorting to Universal Banking framework. An analysis of history is required so that banks can move towards universal banking, only after fully appreciating what lies in store for them.

Universal Bank can be defined as a financial super market offering multifarious products under one roof. However, as mentioned in the Discussion Paper by Reserve Bank of India, the term Universal banking in general refers to the combination of commercial banking and Investment banking i.e., issuing underwriting, investing and trading in securities. In a broad sense, the term Universal banking refers to those banks that offer a wide variety of financial services especially insurance (Reddy, 2000).

\section{Methodology}

This paper is based on secondary sources. Extensive literature review has been done for the period 1994 to 2009. The literature has been grouped under different headings, tracing out the path to universal banking.

\section{Diversification of banking activities in India - a move towards Universal Banking framework}

The Indian Banking system gained much strength and cohesion after the first round of nationalisation of banks in 1969. Nationalisation improved the environment in respect of formulation and implementation of the monetary and banking policies (Dhar, 2004). Post nationalisation period witnessed rapid branch expansion, increase in credit facilities to the priority sectors, and increase in the volume of deposit mobilisation and introduction of various schemes like Lead Bank Scheme, Integrated Rural Development Programme etc.

Early 1980s, India witnessed explosive growth of financial markets. According to Rajadhyaksha (2004), these developments in the Indian Financial sector allowed Companies and sometimes even customers to bypass banks and get money directly from those who save it - a process called disintermediation. This forced banks to enter new business in order to hang on to their precious customers. Moreover, product boundaries have blurred which was also another striking reason for banks to enter into new areas to meet customer needs. And above all, new network technology allowed banks to exploit economies of scale and offer wider range of financial products. All these enabled banks to offer a variety of innovative services in anticipation of materials gains, following a costbenefit analysis (Ho, 2006). In fact, the focus of banks while offering diversified services 
is on customers' demand and satisfying their needs in a best possible way and also on reducing transaction costs and to yield higher profits. Moreover, as customers demanded for variety, convenience, and new services, banks too wanted to provide products that could meet their precise, individual needs. Significantly, the market shifted from being 'seller-centric' to 'buyer-centric' and customers were flooded with offers of a variety of tailor-made products like insurance, mutual fund, stock trading, housing finance etc. under 'one-roof' along with their traditional products (Darshan, 2006). Thus, diversification of banking activities of Commercial banks eventually led to the emergence of Universal Banks in the Indian Financial System.

Rao (2004) noted that deregulation and globalisation of the financial market in India since early 1990s, marked by interest rate competition, relaxation of exchange control and development of I.T. largely facilitated international pooling of financial resources across the world markets. Amidst all these developments, banks started placing more emphasis on new sources of non-interest incomes.

Kannan (2002) mentions that the first impulses of a more diversified financial intermediation was witnessed in the late 1980s and early 1990s, when banks were allowed to undertake leasing, investment banking, mutual funds, factoring, hire-purchase activities through separate subsidiaries. By the mid 1990s, all restrictions on project finance were removed and banks were allowed to undertake several activities in-house. According to the author, reforms in the Insurance sector in the late 1990s and opening up of this field to private and foreign players, also resulted in permitting banks to undertake sale of insurance products. All these have resulted in gradual metamorphosis of Indian commercial banks into Universal banks, offering a variety of financial services.

Another significant fact pointed out by Karunagaran (2005) is that in India, though there is no legislative distinction between Commercial banking and Investment banking or any explicit legislative restriction for the banks to operate in investment banking activities, the banks have traditionally been maintaining the 'arms length' distance from investment banking. However, with the financial sector reforms beginning in 1990s, banks were given abundant freedom to go much beyond their traditional conservative commercial banking and these facilitated banks in providing a host of financial products to meet customer needs. But the more tangible momentum for the emergence of Universal banking concept in India seems to have set in only after the second Narasimham Committee Report (1998) recommending Development Financial Institutions, over a period of time to convert themselves into banks (implicitly Universal banks) and that there should eventually be only 
two forms of intermediation - Banking companies and Non Banking Financial Companies. Moreover, this was followed by a Working Group chaired by S.H.Khan on 'Harmonising the Roles and Operations of Development Financial Institutions and Banks' (1998), which made it more explicit by recommending for a progressive movement towards Universal banking for the DFIs. Significantly, by that time Commercial banks were already permitted to enter diversified areas of financial businesses.

The other driving force behind banks opting for diversification is the development in the field of Information Technology. In fact, it has been IT that has enabled banks to offer a variety of services under one-roof and that too in cost-effective and speedy manner. Many regard computerisation in the banking industry as a key ingredient of the financial sector reform process and it aims to improve customer service, house-keeping, decision-making and productivity and profitability (Suneja, 1994). The RBI, in view of the need of I.T in banking, had formed two high-level committees - one in 1983 under Dr. C Rangarajan and another in the year 1988. Moreover, the enactment of Information Technology Act 2000 by the Government had facilitated the use of IT in the Banking sector. The I.T Act as provided by Section 93 in the Fourth Schedule makes amendment to the Reserve Bank of India Act, 1934 and a new clause pertaining to building a basic legal framework for e-commerce has been incorporated in Section 58 in sub section (2), after clause (p). In fact, I.T has paved the way to speed up the process of banking operations and reduce the drudgery and the time taken in normal banking operations (Vittal, 2001). The introduction of I.T in banking activities has facilitated banks in diversifying their business activities and in turn made the transition path easier for commercial banks in the direction of Universal banking.

Moreover, competition in liberalised markets requires flexibility and reliable information and the Financial System being information intensive, needs a well designed Management Information System (MIS) to serve as a tool for not only risk management but for effective operational management (Murty, 2001). In fact, for effective business decisions, banks need to carry out predictive analysis with 'what if' simulations. With deregulation, many of the barriers to globalisation have vanished and the banking operations are no more restricted to domestic market but have become more global and carried out 24 hours $\times 7$ days a week (Ramaswamy, 2005). With large functional and geographical spread of banks, there has been a sharp growth in the number of accounts in the areas of operation of banks (Talwar, 2000). Thus, increased customer-base, complex products and round the clock services to the customers necessitate the need of modern technology in the banking sector. 
In short, it can be said that diversification in the banking sector has been possible due to financial sector reforms initiated by the Government and Information Technology revolution that swept the country in early 1980s. However, in true terms, diversification in the Banking sector and the acceptance of Universal Banking concept, as different from narrow banking, actually came to the forefront in the Indian context with the second Narasimham Committee (1998) and later the Khan Committee (1998) reports.

Significantly, the recommendations of Narasimham Committee and Khan Committee for consolidation of banking through mergers and amalgamations have brought about a change in the functioning of commercial banks and gradually they are marching towards Universal banking framework (Bhaskar, 2005).

\section{Opportunities}

The gales of financial sector reforms, which started in early 1990s, uprooted many of the outdated regulatory fences within which banks were required to operate. This provided more liberty to banks (Rajadhyaksha, 2004) and they started to diversify their business areas as per permission granted to the banks by the Government under section 6 of the Banking Regulation Act, 1949 (Dhar, 2004). Simultaneously, in the global banking system, there were structural and financial changes, which resulted in large-scale mergers, amalgamations and acquisitions among banks and financial institutions. This led to diversification of business areas of banks, even in India, so as to maximise economies of scale and scope by 'bundling' the production of financial service (Kannan, 2002; Karunagaran, 2005) because the synergies in joint production of financial and non-financial services increase economic efficiency, reduce cost and increase earnings (Bhole, 2004). Moreover, the trend towards Universal banking was expected to result in cost savings in sharing Technology, Information Systems, Accounting Services and Fixed costs (Bhaskar, 2005). It would enable cross selling and increase customer base, reduce transaction costs (in collaboration with Strategic Alliances) and generate more business. Apart from reducing transaction costs and increasing the speed of economic activity, it would ensure continuity of earning revenue with less risk. Another advantage of diversification as pointed out by Ajit (1997) was that in case of low profit/loss in one business, it could be offset by good business in the other area/ units.

Bhalla (2002) asserted that the deregulation of the Indian Financial sector threw up a number of business opportunities. According to him, developments both in the regulatory front as well as from a demographic perspective, would give rise to growing demand for 
certain categories of financial services including insurance and pension funds management, outsourcing, asset management and wealth management etc. Patnaik (2003) opined that the fee-based income could be increased substantially if only banks used their creativity in finding possibility of intermediation, although disintermediation of banking had taken place in case of lending to large corporate. Thus, financial sector reforms provided ample opportunities for banks to diversify and offer a host of financial services under one roof, which was essential for sustenance and also to remain competitive. The author also mentions that, for this, banks need to go for product innovation, enter into strategic alliance with service providers of various kinds, bring revolution in the distribution channels of their products and open subsidiaries with different focus. Mukherjee et al. (2002) feels that the focus of banking institutions should be on understanding the drivers of success, like better utilisation of its resources (like technology, infrastructure and employees), process of delivering quality service to its customers and performance benchmarking or else it would be difficult for them to survive and adapt to the changing environment.

\section{Challenges}

Leeladhar (2006) points out that globalisation has thrown up lot of opportunities before Indian banks but it is accompanied by challenges too. According to the author, banks today face challenges of enhancement of customer service, application of technology, implementation of BASEL II norms, improvement of risk management systems, implementation of accounting standards, enhancement of transparency and disclosures and compliance with Know Your Customer (KYC) aspects in the domestic market while the global challenges include enhancing corporate governance, alignment of regulatory and accounting requirements, outsourcing risks and application of advanced technology.

Sarkar (1999) mentions that with the progressive dismantling of exchange control under the capital account convertibility of rupee, retaining clientele-base would be a challenge to Indian banks. This is because there would be an increase in the flow of both portfolio and foreign direct investment, thereby putting a downward pressure on lending rates. A bank's ability to respond to supply pressures would depend on its cost of funds and operations and failure to remain competitive would lead to loss of clientele, with Corporate and individuals accessing financial markets abroad. Khan (2004) also mentions that in this age of global competition, one of the biggest challenges any service organisation like a bank would face is to meet rising customer expectations. In this context, Lavender (2004) feels that information about customers is the key to increasing sales and instituting 
profitable relationships, so banks need to organise these data to easily differentiate their key customers and prospects and to grow relationships by offering relevant services.

Meanwhile the decision of the Government of India to open the banking sector to foreign participants after 2009, has thrown an open challenge to Indian banks to attain operational efficiency (Rajadhyaksha, 2005). With this, competition in the banking sector was expected to go up further. Moreover, with the emergence of new generation Private Sector Banks and Foreign Banks in the country, Indian Non Banking Financial Companies and Financial Institutions realised that to sustain competition, they needed to offer diversified services under one-roof. Thus, these institutions were also caught up with the idea of transforming into Universal Banks.

Again with the lowering of entry barriers and blurring product lines of banks and non-banks, since the financial sector reforms, banks were functioning under increasing competitive pressures. Hence, it was imperative that banks maintained a loyal customer base (Choudhury, 2007). To achieve this and to improve their market and profit positions, many retail banks will have to direct their strategies towards increasing customer satisfaction and loyalty through improved service quality. Furthermore, with the advent of international banking, trend towards larger bank holding companies, and innovations in the marketplace, customers are confronting greater and greater difficulty in differentiating and selecting one banking institution from another. Therefore, the current problem or rather a challenge for the Indian banking industry is to determine the dimensionality of customer-perceived service quality. This is because if service quality dimensions can be identified, service managers should be able to improve the delivery of customer perceived quality during the service process and have greater control over the overall outcome.

Thus, the Banking industry in India was forced to change rapidly as a result of open market forces such as the threat of competition, customer demand, and technological innovations like the growth of Internet. If banks are to retain their competitiveness, they must focus on customer retention and relationship management, upgrade and offer integrated and value added services, form strong alliance and joint ventures with other Non-Banking entities. In short, banks need to adopt innovative banking (Mithani, 1992) for deposit mobilisation and deployment of credit and that too, through customised products.

\section{Risks Confronted}

Deregulation and globalisation of Indian Banking sector provided ample opportunities for growth of banks. In the course of financial intermediation, banks were 
confronted with various kinds of financial and non-financial risks viz., credit, interest rate, foreign exchange rate, liquidity, equity price, commodity price, legal, regulatory, reputation, operational etc. The risks referred to above are interconnected and interdependent and these risks faced by banks arise on account of a number of factors like the policies pursued by the Government, increased competition, reduced spreads, more and more sophisticated clients and last but not the least, the developments in information technology and telecommunications (Joshi \& Joshi, 2002).

With diversification of banking operations, banks started having substantial interests in all sorts of financial businesses. Gradually, these banks began moving towards the Universal banking framework. Such an entity then happens to be a dominant player in the economy and its failure results in emergence of systemic risk (Herring \& Litan, 2003; Rajadhyaksha, 2004). However, effective regulatory initiative to identify the system weaknesses and understand early signals can contribute to substantial reduction in system risk and as such banks have to be managed and regulated with great care. Moreover, when an entity offers diversified financial services under one-roof, it raises additional supervisory concerns due to the emergence of additional risks. The principal additional risks arise because of contagion, conflicts of interest, lack of transparency and regulatory arbitrage (Sundararajan $\&$ Baldwin, 2005). Contagion arises when financial problems are transmitted among the group entities as well as between groups. Again banks within the conglomerate are at a risk of a loss of confidence arising from negative publicity about the activities of an affiliate or they may be drawn into the problems of an affiliate if group management pressurises the bank to support the troubled affiliate. Such conflicts of interest are often faced by the management of financial groups and the decisions that benefit the group as a whole may not be in the best interest of a particular group entity. In such instances, there is a probability that banks may suffer either from reputation risk or from additional risks that arise not because of its own business operations but for being a part of a financial group.

As banks are allowed to go for diversification of businesses, banks world over, are continuing their efforts to diversify their income source and as such they need to manage diversification risk i.e., managing the risk arising from the new intermediation activities (Yam, 2004). Furthermore, Yam (2004) points out that awareness of customers about their consumer rights have increased, thus exposing banks to greater compliance, legal and reputation risks, when venturing into new areas of activities.

Another important fact which bankers cannot ignore is that 'safe and efficient payments systems' are critical to the effective functioning of any financial system (Clacher et al., 
2006). If they are poorly designed then shocks can be transmitted between markets and institutions. When default occurs in transactions, then the effect is amplified and may spread due to structural inefficiencies in the system. The effect is that institutions may experience liquidity and credit problems, which could endanger the stability of the payments systems and wider financial markets. Again, in many emerging markets like India, the majority of transactions are through paper, cheques, and drafts and therefore, the inefficiency is obvious. This eventually can lead to financial crisis.

With increased competition in the Indian Banking sector, banking is no longer regarded as a business dealing with money transactions alone, but is also seen as a business related to information on financial transactions. It is believed that I.T. plays a significant role in providing better customer service, presumably at a lower cost. Several innovative I.Tenabled services such as ATM, Electronic fund transfer, Anywhere-Anytime banking, Smart cards, Net Banking etc. are adopted by banks (Sureshchandar, Rajandran \& Anantharaman, 2003). This exposes banks to technology risk as well as operation risk.

Moreover, market volatility, corporate irregularities and troubled capital markets have shaken the banking industry and highlighted the dangers of poor risk management. Traditional risk systems cannot capture the interrelationship between various risks types across geographies, departments, and lines of business. And the new BASEL Capital Accord is driving banks to adopt more comprehensive risk management systems to survive and succeed. In the aspect, Fell and Devine (2003) mention that as banks have substantial interests in various financial businesses, they confront credit, market, operational, insurance, liquidity, and group risks, which are also brought under the purview of the FSA Integrated Prudential Sourcebook for ensuring stability of the system.

Efforts are made by the Bank Management as well as Regulators across globe to manage risk of the banking sector effectively. In India, the RBI uses the CAMEL Model (as suggested by BIS) to assess the risk exposure of banks so as to ensure stability of the Indian Financial System. C.A.M.E.L.S is an acronym and stands for Capital Adequacy, Asset Quality, Management, Earnings Quality, Liquidity and Sensitivity to Market Risk. The C.A.M.E.L.S model is used to assess the health of a financial institute.

\section{The Regulatory System for monitoring Banks offering diversified financial services}

Banks, unlike other organisations, are different due to plasticity of assets and high debt/equity ratios (Hickson \& Turner, 1996). And it is an acknowledged fact worldwide that banks are very fragile institutions, which are built on trust, reputation and dangerous 
leverage. In times of trouble, banks can collapse like a pack of cards and failure of one bank can send shock waves right through the economy. Therefore, banks are subjected to statutory regulations so as to ensure that banking and financial activities do not lead to 'moral hazard'. As most of the banks are often 'too big to fail', it is likely that they may take more risks under the assumption that the Government will step in with a bailout in case something goes wrong (Rajadhyaksha, 2004). Such general inertia, according to Karunagaran (2005), would only encourage the banks especially those of Universal Banking framework to indulge in high-risk activities. Moreover, the theory 'too big to fail' has lost its relevance (Karunagaran, 2005). It is because of this reason that Financial System, world over, has been stringently regulated, even in case of open economy, where market takes a leading role. The rationale behind such requirement was that regulation and supervision was required to correct 'market failure' as banks tend to take more risks than the prudent limit, which will in turn have an adverse impact on the system. And India is no exception to this.

Herring \& Litan (2003) states that as far as regulation is concerned, there is no settled model: some nations will pursue consolidated supervision, with authority over entire conglomerates vested in a single authority like the Financial Services Authority of the U.K., while others will still regulate the pieces of diversified financial enterprises along structural lines like in India, where such an entity is required to report to different authorities like Reserve Bank India (RBI), Securities Exchange Board of India (SEBI), Insurance Regulatory \& Development Authority (IRDA), National Housing Bank (NHB) and Pension Fund Regulatory and Development Authority (PFRDA). While the specific objective of these regulators may vary from depositor protection and investor protection to market regulation, their common concern is maintaining financial stability (Reddy, 2001).

The Financial Service Authority is the single regulator in the United Kingdom for banks and financial services companies. It is a statutory body governed by Financial Services \& Markets Act, 2000 and is an independent and non government body concerned with maintaining confidence in the financial system, promoting public understanding of the system, securing the appropriate degree of protection for consumers and reducing financial crime (Slattery \& Nellis, 2005). Even in the USA, the Gramm Leach Bliley Act (GLBA) had also proposed for an integrated supervisory model called the Federal Reserve, which acts as an umbrella regulator - especially aimed at supervising the financial system or conglomerates (Rajadhyaksha, 2004; Karunagaran, 2005). Thus, it is felt that in India, regulatory arbitrage could be minimised if a unified Regulatory Authority, as against the 
present system of multiple regulators, regulates the System. In fact, the arguments in favour of unification of regulatory agencies are based on the fact that a unified regulator would ensure competitive neutrality in the light of the blurring distinctions between the various classes of financial institutions (Sundararajan \& Baldwin, 2005).

However, according to Sundararajan \& Baldwin (2005), there are certain arguments against unification. It is thought that unification will result in unclear objectives for the regulatory agency and even diseconomies of scale may arise because a unified agency is effectively a regulatory monopoly and may give rise to the type of inefficiencies usually associated with monopolies. Above all, it may extend moral hazard concerns across the whole financial services sector as the public will tend to assume that all creditors of institutions supervised by a given regulatory agency will receive equal protection. In spite of these arguments against unification, in India, the adoption of principles of consolidated supervision is being progressively bridged.

According to Sharma \& Vashishtha (2007), the recent developments in the financial sector, in particular, the emergence of financial conglomerates, have led to an appreciation of the limitations of the present segmental approach to financial regulation. The need for addressing the risks associated with conglomeration is being widely appreciated. A debate is going around as regards the ways and means of ensuring an effective regulatory system, which has the qualities of neutrality, cost-effectiveness, transparency and accountability, and above all which suits the political and social structures and commitments as well as the government, industry and societal inter-relations. Thus, according to the authors, in this on-going debate, there is a consensus on adopting a consolidated, holistic supervisory approach to financial regulation and supervision, irrespective of its structural design. The RBI, recognising the relevance and effectiveness of regulatory problems posed by the emergence and growth of financial conglomerates, took the first step towards consolidated supervision of banking entities by issuing guidelines to the Banks in February 2003 on the basis of Working Group Report (RBI, 2004). In the light of these, the authors have suggested a model. The model is termed as holistic in a sense that it attempts to look at financial markets as continuously evolving entities, irrespective of traditional sectoral distinctions and accordingly delivers supervision which is more effective in handling the challenges of regulatory arbitrage, financial conglomerates and cross border integration of domestic financial sector. 


\section{Conclusion}

Technically in India, it is only ICICI Bank which has been officially designated as Universal Bank. However it is seen that most of the banks are offering services which will very well qualify under the concept of universal banking. Financial sector reforms in early 1990s provided the Indian banking sector the much need impetus for growth and diversification into different areas of business. Banks opted for diversification so as to maximise 'economies of scale and scope' (Kannan, 2002; Karunagaran, 2005) because the synergies in joint production of financial and non-financial services increase economic efficiency, reduce cost and increase earnings (Bhole, 2004). Moreover, globalisation, deregulation and advances in Information Technology in recent years brought about a significant change in the operating environment for banks. This facilitated many Indian banks to have substantial interests in different financial businesses so as to maximise economies of scale and scope. Thus, in other words, it can be said that deregulation of Indian Financial System has paved the way for diversification and rise of financial conglomerates. And the phenomenon of financial conglomerates has necessitated serious consideration of a shift in regulatory paradigm (Sharma \& Vashishtha, 2007).

Although there are several benefits of Universal banking, these benefits have to be weighed out against the problems. The obvious drawback, according to Sensarma (2001), is that Universal banking leads to a loss in economies of specialisation. In fact, diversifications of banking activities need not always result in economies of scale and scope especially if banks are not of appropriate size (Herring \& Litan, 2003; Karunagaran, 2005). On the contrary, it might even prove to be more expensive, if sufficient number of transactions in each of the specialised financial activity is not even up to the 'breakeven' level. Moreover, Harissis et al. (2009) points out that banks and insurers across Europe and worldwide have rushed into mergers with one another, hoping to reap economies of scale and boost revenues by cross-selling. But unfortunately the phenomenon has not been welcomed in all geographic regions, and cross-selling has turned out to be more difficult than expected. Moreover, according to Costanzo \& Ashton (2006) bank customers are often unfamiliar with, and lack confidence when, buying savings products. And as the financial market is flooded with undifferentiated products, consumers may find it even more difficult to make a straightforward comparison between products. Thus, offering diversified products may not result in increased revenue for banks.

Again there is a possibility that the multi-product banks would lose sight of their core competence and would face greater risk by participating in untested activities. Bhole (2004) 
has pointed out that diversification of banking activities and their eventual transition towards Universal Banking framework would aggravate the problem of concentration of financial and economic power, creation of financial and industrial oligopolies and conglomerates. This might maximise private commercial gains but not social benefits, as large combinations and their unrestricted growth do not lead to socially best allocation of resources.

\section{REFERENCES}

Ajit, D. (1997, Oct. 18-24). Para banking in India -Some issues. Economic and Political Weekly, 32 (42): 2677-2686. Bhalla, V.K. (2002). Management of sinancial services. New Delhi: Anmol Publications Private Limited.

Bhaskar, P.V. A. (2005, March). Trend towards universal banking with strategic alliances. IBA Bulletin, XXVII (3): 8-11. Bhole, L.M. (2004). Financial institutions and markets: Structure, growth and innovations. (4 $4^{\text {th }}$ ed.). New Delhi: Tata McGraw Hill Publishing Company Limited.

Choudhury, K. (2007). Service quality dimensionality: A study of the Indian banking sector. Journal of AsiaPacific Business, 8 (4): 21-38.

Clacher, I., Doriye, J., Mohamed, S.R., \& Satta, T. (2006). Challenges facing banking in emerging markets A case study of the Tanzanian national payments systems. Journal of Financial Regulation and Compliance, 14 (1): 112-118. DOI: 10.1108/13581980610644798

Costanzo, L. A., \& Ashton, J.K. (2006). Product innovation and consumer choice in the UK financial services industry. Journal of Financial Regulation and Compliance, 14 (3): 285-303. DOI:10.1108/13581980610685658.

Darshan, N.V. (2006, October). The growth of banks as finanacial super markets. The Indian Banker, I (10): 15-18.

Dhar, P.K. (2004). Indian economy -Its growing dimensions. (12 $2^{\text {th }}$ ed.). (pp. 689-744). India: Kalyani Publishers.

Fell, P., \& Devine, M. (2003). The FSA integrated prudential sourcebook-A walk through. Balance Sheet, 11(1): 62-88. DOI: 10.1108/09657960310698191.

Harissis, H. F., Merikas, A., Mutenga, S., \& Staikouras, S. K. (2009). Universal banking and stock-market reaction-Some evidence from major announcements. The Journal of Risk Finance, 10 (3): 244-260. DOI: $10.1108 / 15265940910959375$.

Herring, R. J., \& Litan, R. E. (2003). Financial conglomerate: The future of finance? [online]. Available: http:// www.brookings.edu/comm./conferencereport/cr/14.html.

Hickson, C., \& Turner, J. (1996). Banking regulation's impact on industry monopoly and risk. European Business Review, 96 (5): 34-42. DOI: 10.1108/09555349610127977.

Ho, N.W. (2006). Financial innovation and its impact on central-bank policies. [online]. Available: http://www. amcm.gov.mo/publication/Financial\% 20 Innovation_en.pdf.

Joshi, V. C., \& Joshi, V. V. (2002). Managing Indian banks- Challenges ahead. (pp. 117-147). India: Response Books.

Kannan, R. (2002).Universal banking, [online]. Available: http://www.geocities.com/kstability/inbank2/finub/ universal.html (2006, May 24)

Karunagaran, A. (2005, January). Towards universal banking in India: Some regulatory and supervisory issues. IBA Bulletin, XXVII (1): 139-144.

Khan, M. M. (2004, December). Customer retention strategies in globalising Indian banks. Banking Finance, 8-13.

Khan, S.H. (1998). Report of the working group on harmonising the role and operations of development financial institutions and banks. IDBI. 
Lavender, M. (2004). Maximising customer relationships and minimising business risk. International Journal of Bank Marketing, 22(4): 291-296. DOI:10.1108/02652320410542563.

Leeladhar, V. (2006). Indian banks and global challenges,[online]. Available: http:// www.indiainfoline.com/ nevi/leel.html (2006, June 7)

Mithani, D.M. (1992). Money banking international trade and public finance. (6 ${ }^{\text {th }}$ ed.). (pp. 369-370). India: Himalaya Publishing House.

Mukherjee, A., Nath, P.R., \& Pal, M. N. (2002). Performance benchmarking and strategic homogeneity of Indian banks. International Journal of Bank Marketing, 20 (3): 122-139. DOI: 10.1108/02652320210430965

Murty, G.R.K. (2001, March). Credit-risk management in a market driven economy: The acid test for banks. IBA Bulletin, XXIII (3): 105-123.

Narasimham, M. (1998). Report of the committee on banking sector reforms. Government of India.

Patnaik, J. (2003, February). Disintermediation in banks. Banking Finance, 20-21.

Rajadhyaksha, N. (2004, November). The rise of financial conglomerates. Business World, 28-33.

Rajadhyaksha, N. (2005, July). The future of Indian banking. Business World, 26-43.

Ramaswamy, V. (2005, May). Operational risk management-Systems and process. IBA Bulletin, XXVII (5): 19-22.

Rao, V.K. B. (2004, November). Paradigm of universal banking. Banking Finance, 23-25.

Reddy, Y.V. (2000). Universal banking and beyond. In Kapila, Raj., \& Kapila, Uma (Eds.), Ongoing Developments in Banking and Financial Sector. (pp. 33-45). India: Academic Foundation.

Reddy, Y. V. (2001, June). Issues in choosing between single and multiple regulators of financial system. IBA Bulletin, XXIII (6): 8-19.

Reserve Bank of India. (2004, June). Report on monitoring of financial conglomerates. Government of India.

Sarkar, J. (1999). India's banking sector: Current status, emerging challenges and policy imperatives in a globalised environment. In Hanson, James A., \& Kathuria, Sanjoy (Eds.), India: A Financial Sector for the Twenty-first Century. (pp. 71-129). India: Oxford University Press.

Sensarma, R. (2001, October). Do we need universal banking in India? Banking Finance, 27-28.

Sharma, A.K., \& Vashishtha, A. (2007). Dynamics and regulatory system of Indian financial markets: A dialectic view. Journal of Financial Regulation and Compliance, 15 (3): 275-302. DOI: $10.1108 / 13581980710762282$.

Slattery, D. J., \& Nellis, J. G. (2005). Product development in UK retail banking. International Journal of Bank Marketing, 23(1) : 90-106. DOI:10.1108/02652320510577384.

Sundararajan, V., \& Baldwin, B. (2005). Regulation of financial conglomerates: Is unification of financial sector supervision the answer. In Mohan, T.T. Ram., Rege, Rupa., \& Nitsure, Mathew Joseph (Eds.), Regulation of Financial Intermediaries on Emerging Markets. (pp.118-162). India: Response Books.

Suneja, H.R. (1994). Innovations in banking services. India: Himalaya Publishing House.

Sureshchandar, G.S., Rajandran, C., \& Anantharaman, R.N. (2003). Customer perception of service quality in the banking sector of a developing economy: A critical analysis. International Journal of Bank Marketing, 21(5): 233-242. DOI: 10.1108/02652320310488411.

Talwar, S.P. (2000). Information technology and the banking sector. In Kapila, Raj \& Kapila, Uma (Eds.), Ongoing Developments in Banking and Financial Sector, 3: (pp. 91-101). India: Academic Foundations.

Vittal, N. (2001, March). The emerging challenges: Strategies and solutions for Indian banking. IBA Bulletin, XXIII (3): 9-14. Yam, J. (2004). Banking sector risks and challenges, [online]. Available: http://www.bis.org/review/ r040618f. html (2006, May 26) 